\title{
Voting with Your Fork? \\ Industrial Free Range Eggs and the Regulatory Construction of Consumer Choice
}

\author{
Christine Parker (Monash University) \\ Please cite official version published in Annals of the American Academy of Social and \\ Political Science, 2013, 649, 52-73. DOI: 10.1177/0002716213487303
}

\begin{abstract}
Labeling and information disclosure to support consumer choice are often proposed as attractive policy alternatives to onerous mandatory business regulation. This article argues that choices available to consumers are constructed and constrained by actors in the chains of production, distribution, and exchange who bring products to retail. I trace how "free range" eggs come to market in Australia, finding that the "industrial freerange" label dominating the market is not substantially different from caged-egg production in the way that it addresses animal welfare, public health, and agro-ecological values. I show how the product choices available to consumers have been constructed not just by the regulation (or nonregulation) of marketing and labeling, but also by the regulatory paths taken and not taken all along the food chain.
\end{abstract}

NOTE: I am grateful to Jane Kotey and Carly Brunswick for much dedicated research assistance in collecting the data and literature for this article. I am also grateful to Chris Arup, Elizabeth Brophy, Nathan Harris, David Levi-Faur, Leslie Levin, Peter Mascini, Janette Nankivell, Gyorgy Scrinis, and Julie Umek for ongoing conversations and moral and practical support in relation to this work. 
In 2012, the Australian industry association for egg producers, Egg Corporation Limited ("Egg Corp"), generated huge controversy and publicity when it applied to the Australian Competition and Consumer Commission (ACCC) for approval of its revised and rebranded quality assurance certification trademark. At face value, the Egg Corp scheme is an ordinary quality assurance accreditation scheme with a trademarked logo similar to those used in many industries to ensure good management and the reliability, consistency, and safety of goods and services. Such applications are usually approved as a matter of course by the ACCC as being of overall benefit to consumers despite their potential anticompetitive effect. However, the ACCC received 1,700 submissions in relation to this application, all but seven opposing approval (ACCC 2012). Controversy centered on one aspect of this wide-ranging quality assurance scheme - its definition of a "free range" production system for the purposes of egg labeling. Critics said that Egg Corp's definition was misleading and deceptive because it was designed to allow intense production at stocking densities that would not meet the conditions most consumers expected of "free range." Egg Corp, however, argued that this definition was necessary to allow consumers to buy "free range" eggs at a reasonable price. Indeed, Egg Corp argued, its existing ACCC-approved quality assurance certification system already allowed eggs laid by hens kept at much higher stocking densities to be labeled and sold as "free range.",

It is hardly surprising that the definition of "free range" is hotly contested. Eggs are big business. Global per capita egg consumption has doubled since 1950 (Weis 2007).

Australian egg consumption is rising, from lows of around 140 eggs per capita in the 1980s and 1990s to 213 eggs per capita (Australian Bureau of Statistics [ABS] 2011; Australian Egg Corporation Limited [AECL] 2011) and production worth \$572 million in 2011 (AECL 2012a). Per capita consumption is even higher in the United States, averaging 248 eggs in 2012 (American Egg Board 2012). Most egg production globally, including that in Australia and the United States, uses the cage systems introduced in the 1960s as production intensified and industrialized ${ }^{\mathrm{ii}}$ (Sharman 2009), but the popularity of noncaged eggs is growing. In Australia "free range" lines accounted for 28.4 percent of carton egg sales in 2011, up from 14.5 percent in 2005 (AECL 2005, 2006, 2007, 2008, 2009, 2010a, 2011). ${ }^{\text {iii }}$ Consumers pay a premium for cage-free eggs. The average price for a dozen eggs in Australia in 2010 was AUD\$4.00 (AECL 2011), but in 2012 a dozen "free range" eggs commonly cost AUD\$6.00 (or AUD\$8.00 if they are "organic") at one of Australia's two dominant supermarket chains (Coles and Woolworths), and more than AUD\$10.00 when purchased at alternative organic and wholefoods stores. ${ }^{\text {iv }}$

In food policy, "voting with your fork" or "shopping for change" is proposed as a powerful way to change the food system (Pollan 2006, Roff 2007). Australian journalist, farmer, and food activist Dianne Loughnan $(2012,71)$ writes, "Shoppers are entitled to know what they are buying and how it was produced. ... Shoppers who don't wish to support unethical egg production systems should vote with their dollars, as this is one instance where supply is definitely driven by demand." She goes on to give the example of Coles simultaneously phasing out cage eggs and dropping the price of free range eggs (p. 72).

In regulatory policy, labeling and information disclosure to support consumer choice are often lauded as important alternatives to onerous mandatory regulation. Instead, informed and engaged consumers can, through their individual choices, change the behavior of powerful organizational actors for the better (Fung, Graham, and Weil 
2007). This article argues, however, that consumers cannot bring an alternative product into existence through the power of choice alone: the choices available to consumers have already been constructed and constrained by relationships among actors in the production, distribution, and exchange chain who bring products to retail. A new set of relationships and actions - including different farming practices, different relationships with the hens and ecology, and often different distribution systems and retail outletsmust be created for a consumer to have product choices that expresses different values (see Morgan, Marsden, and Murdoch 2009; Sewell 1992; Swidler 1986). A range of regulatory choices will construct or stabilize, defend or destroy these chains of relationships and action. Some of these regulatory strategies will be formal, some informal, some based in government, and others based in industry or civil society (see Levi-Faur forthcoming).

This article traces the way the "free range" egg choices available to retail consumers have been constructed not just by regulation (or non-regulation) of marketing and labeling, but also by which parts of the food chain that lies behind the retail products are regulated and not regulated, and in which ways.

The research on which this article is based uses a combination of visual sociology (Richards, Lawrence, and Burch 2011, 38-39), ground-up institutional ethnography (Smith 2005; see also Ewick and Silbey 1998), value chain analysis, and analysis of regulatory design, enforcement and compliance (Parker and Nielsen 2011, 2009). The second part of the article briefly describes the data collection and analysis methods. The third part of the article shows how Egg Corp's quality assurance scheme was explicitly created as an "industry-led," "consumer choice" alternative to banning caged egg production or at least requiring "enriched" or "colony" cages as has been done in the European Union (EU) and New Zealand. ${ }^{\mathrm{vi}}$

The fourth part shows that the types of "free range" eggs now available to consumers in Australia and the meaning of the label depend largely on the retail space in which the eggs are sold, with different types of retail outlets being the visible ends of distinct egg food chains that institutionalize significantly different values and relationships. The conclusion presents the implications of these findings for policy directions, market structure, and consumer choice.

\section{METHOD}

The data collection is recursive, beginning and ending with the researcher in the place of the retail consumer seeking to buy "free range" eggs. The researcher and her assistants bought every variety of noncaged ("free range," "organic,"vii and "barn-laid") eggs for sale in Canberra, Melbourne, and Sydney, Australia, in 2012 at a variety of supermarkets, green grocers, urban markets, organic and wholefoods stores, and farmers' markets. We noted how the eggs were displayed and sold, the branding and labeling on the actual carton and on any associated websites, and what claims were made - explicitly (in written or spoken word) and implicitly (in pictures, signs, and symbols; and by context) - about the meaning of "free range" (see also Parker, Kotey, and Brunswick, forthcoming).

We paid particular attention to whether retail product presentation appealed to any regulatory support, such as a voluntary accreditation system. Each accreditation system and logo that we encountered was researched in some detail, including interviewing those responsible for each accreditation system and farmers who did and did not use 
accreditations. We also examined policy debates, social media, and activist campaigns to uncover how regulation and food chain arrangements create what is visible to the consumer and how the marketing, sale, and production of eggs, especially free range, have been contested.

We then returned to the consumer's view of free range eggs. Our final analysis critically examined what the labels, websites, and contexts of sale said about the eggs' production versus what the research found to be accessible to those who wish to vote with their forks. Most importantly, it critically examined how regulation has (and has not) been used to help construct and contest both the representations made to the consumer and the relationships and practices further back in the food chain.

\section{A CONSUMER CHOICE APPROACH TO CAGED- AND FREE-RANGE EGG PRODUCTION}

\section{The movements against caged eggs and for free range}

In Australia (as elsewhere in the developed world), the popularity of free-range eggs has grown out of animal welfare advocates' campaigns to ban battery caged egg production; consumers who want to reduce the distance between themselves and the people producing their food; and support by alternative farmers, food lovers, and activists for small-scale, organic, pastured, and ecologically sustainable farming practices (e.g., Loughnan 2012, Miele and Evans 2010).

Animal welfare advocates, such as Animals Australia and the Royal Society for the Prevention of Cruelty to Animals, have long campaigned for a complete ban on caged egg production throughout Australia, and, in the meantime, for consumers to "buycott" caged eggs. ${ }^{\text {vii }}$ The animal welfare problems with caged egg production, especially battery cages in which hens are kept in a barren wire cage, are well known. It is often noted that layer hens are the animals most intensively farmed and that endure the harshest conditions in human agriculture (Loughnan 2012, 58). Australian regulation provides a minimum floor space for each hen of only about the size of an A4 sheet of paper (i.e., $627 \mathrm{~cm}^{2}$, or close to Letter size paper) (Primary Industries Standing Committee 2002). ${ }^{\text {ix }}$ Regulation also provides that chickens must be able to stand naturally in the cage and have access to water, but there are no requirements for nests, perches, or access to a feed trough. Sheds are atmosphere-controlled, with lighting and climate artificially set (Loughnan 2012). One conveyor belt runs along the front of the cages and delivers a grain mix to the birds, while another belt behind collects the eggs (Loughnan 2012). After 18 months, laying 300 eggs per year, the hens are considered "spent" and are ground up to make stock and pet food (Loughnan 2012; Royal Society for the Prevention of Cruelty to Animals [RSPCA] 2012a).

The space provided is insufficient to permit hens to spread their wings or turn around (Weis 2007, 60), let alone perform natural behaviors of preening, nesting, perching, foraging, and dust bathing (Pickett 2003; RSPCA 2012b). Hens exhibit an array of problematic behaviors and health issues; they become de-feathered (caused by rubbing up against the wire of the cage), get their feet entangled or trapped in the wire floor, develop weakened bones and broken legs (due to lack of exercise, sunlight, and cramping), and partake in trampling, pecking to death, and cannibalization (due to cramped conditions and lack of ability to exercise cognitive and social potential). To hamper pecking, chicks have part of their beaks removed with a heated blade (known as 
“de-beaking” or "beak-trimming” ), causing trauma and often leaving birds in chronic pain (Sharman 2009, 43). To address the voluminous amounts of fecal matter birds come into contact with, antibiotics are often added to the hens' feed and the air is sprayed with chemical disinfectants (Weis 2007, 61). To force industrial hens to continue laying, producers often manipulate lighting conditions and feed to reduce hens' rest periods. The increased production reduces hens' bone strength, health, and immunity to disease (Loughnan 2012, 60-62).

While the campaign to ban battery cages has generally focused on animal welfare, alternative free-range farm practices have been created by farmers and foodies who are often equally concerned with the health and agro-ecological issues of intensive animal production. The concentration of thousands upon thousands of chickens in poor physical conditions certainly poses systemic hazards to public health. Cesspools of chicken manure release toxic compounds into the air, which can cause inflammatory, immune, and neurological problems in humans (Wiley et al. 2004). The UN' s Food and Agricultural Organization linked the development of the H5N1 strain of avian influenza, which can infect humans, to industrial-scale clustering of poultry for food production (Nierenberg 2005; Weis 2007). Likewise, research has found that forced moulting suppresses hens' immune systems, allowing a 100- to 1000-fold increase of Salmonella Enteritidis (Loughnan 2012). The indiscriminate use of pharmaceuticals to stimulate growth and prevent disease also leads to the development of antibiotic-resistant bacteria and deadlier infectious diseases that affect humans (McKenna 2010; Weis 2007).

The intensive factory farming of layer hens also necessitates large inputs of feed, the production and often long-distance transport of which contribute to loss of habitat and biodiversity, and to the dependence on the use of chemical fertilizers, pesticides and fossil fuels (WSPA n.d.). Locally, industrialized farming practices affect the soil, air, and water. On mixed, integrated farms, the fecal matter from small populations of animals acts as a fertilizer in rotation with grains, legumes, and pasture, thus maintaining healthy, productive soils. On industrial-scale egg farms, the chicken feces must be collected, sold, and transported to other farms to act as fertilizer, otherwise it is dumped in cesspools that contaminate the surrounding air and water (Weis 2007).

The adverse animal welfare and environmental impacts of industrialized egg production led small pockets of farmers in Australia, the United States, and elsewhere to develop accreditation bodies to recognize alternative farming methods. Members of the Free Range Farmers' Association (FRFA) in Australia, for example, agree to independent auditing of all farms, no de-beaking of hens, traceability of eggs, and the prohibition of mixed systems (i.e., farming both free range and barn-laid eggs). ${ }^{\mathrm{x}}$ The Humane Society International started a similar body, Humane Choice, after being approached by an Australian pig farmer who wanted to see animal welfare and environmental concerns given equal attention within one certification scheme. ${ }^{\mathrm{xi}}$ The failure to ban cages

In 1999, the EU responded to activism against battery cages by issuing a directive that all member countries must phase out and ban battery cages by 2012 to allow only "enriched" cages. ${ }^{\text {xii }}$ This prompted the Australian Council of State and Territory Agriculture Ministers (ARMCANZ) to consider whether Australia should follow suit. Their 2000 report recognized that an "increasing proportion of the general community" opposes "conventional laying cages on animal welfare grounds" (SCARM Working 
Group 2000, 25) but concluded that it was not appropriate to burden industry with the cost of mandating enriched cages (SCARM Working Group 2000, 3). One important reason for this decision was that the fastest growing and most cost-sensitive aspect of the egg industry is the sale of eggs for use in processed foods and that part of the industry (32 percent of the market for eggs in 2000 and 42.1 percent in 2012) (Outlaw 2012) could conceivably be lost to Asian producers of dried or liquid egg products if battery cages were banned (SCARM Working Group 2000, 25). ${ }^{\text {xiii }}$ The promotion of Australian production overruled animal welfare and demonstrated another way in which supply chains constrain consumer choices.

The agriculture ministers concluded in their report that caged- and cage-free egg production raised different animal welfare problems and could not be meaningfully compared and ranked, at least not at a commercial scale with thousands of birds in the same facility. However, since many consumers felt that noncaged eggs were better, the report proposed an "industry-led," "consumer choice" approach in which three types of eggs would be clearly differentiated and labeled: "cage," where birds are "continuously housed in cages (generally battery cages) within a shed"; "barn," where birds "are free to roam within a shed which may have more than one level"; and "free range," where birds "are housed in sheds and have access to an outdoor range" (SCARM Working Group 2000 , 4). ${ }^{\text {xiv }}$ The report described a "vision" of the "quality-assured health and welfare of fowls in a commercially viable, competitive and environmentally friendly egg industry producing a regular, reliable and affordable supply of eggs allowing for informed choice by consumers and according to contemporary standards for food safety and occupational health" (SCARM Working Group 2000, 3-4). Animal welfare was, therefore, redefined as a private good for which consumers could choose to pay an ethical premium, not a public good that warranted more than minimal mandatory regulation (see Cao 2010; Dale 2009). The agro-ecological and public health impacts of concentrated layer hen facilities were not considered at all. A subsequent 2011 inquiry into food labeling by the Independent Panel for the Review of Food Labelling Law and Policy (IPRFLLP), commissioned by the Australia and New Zealand Food Regulation Ministerial Council, confirmed this approach and unequivocally determined that the choice of caged versus cage-free is a "consumer values" issue that should not be the subject of mandatory regulation at all, not even legislatively mandated definitions of what counts as "free range" (IPRFLLP 2011, 20, 33, 48).

The agriculture ministers' 2000 report suggested that a national quality assurance system to help industry comply with all the legal requirements for egg production, particularly food safety, bio-risk security and animal health, was the most urgent need. Egg Corp developed its voluntary quality assurance system as a direct response to this suggestion. Under this scheme, egg producers implement a management system, which is audited by Egg Corp, so that they can appear on a list of accredited producers and use the "Egg Corp Assured" logo. In line with the overall policy approach, assurance that the eggs are accurately labeled as caged, barn-raised, or free range is only one minor aspect. It is not clear that Egg Corp auditors actually check outdoor stocking densities, access to the range, or the conditions of the range when they visit production facilities, although they do check indoor stocking density. ${ }^{\mathrm{xv}}$

Moreover, the current Egg Corp scheme puts no limits on outdoor stocking density. ${ }^{\text {vi }}$ Consumer, animal welfare, and small-scale organic and free-range farmer 
groups argue that the relevant guidelines in the voluntary Model Code of Practice for the Welfare of Animals for Domestic Poultry should be interpreted as requiring a maximum stocking density of 1,500 hens per hectare (about .004 miles) outdoors for eggs to be labeled "free range." Egg Corp, however, in line with the interests of larger, more concentrated egg producers, interprets the relevant provisions as putting no maximum on stocking density. In 2012, Egg Corp claimed that " $29 \%$ of free-range egg production in Australia stocks at densities higher than 2 hens per square meter $(20,000$ per hectare) on the range area" (AECL 2012b) and that this complies with their scheme. However, Egg Corp said that it "does not consider this to be appropriate," and its new, revised (and controversial) quality assurance system would "address this and draw a 'line in the sand' at a responsible and transparent maximum outdoor or range density" $-20,000$ hens per hectare (AECL 2012a). In late 2012, the ACCC made a preliminary decision rejecting Egg Corp's revised scheme, and Egg Corp subsequently withdrew its application (ACCC 2012). Egg Corp's original scheme, with no limits on stocking density, continues to operate. Table 1 compares the requirements for free range in that scheme with those in the alternative schemes described below.

[Table 1 about here]

TABLE 1

\section{Summary of Major Accreditation Standards for Free-range Egg Production in} Australia

Activists are now campaigning state by state for mandatory labeling and legislated definitions of free range, and the possibility of such legislation is one of the reasons for the controversy over Egg Corp's revisions to its quality assurance scheme. Egg Corp wishes to continue to stave off legislation, while many activists and alternative producers believe that legislation would improve consumer choice by wresting the definition of "free range" from Egg Corp and putting it under more democratic control. Currently, the only state with such legislation is the Australian Capital Territory (Canberra), and our analysis found no difference in the eggs available for retail sale in that state compared with other states. ${ }^{\text {xvii }}$ This similarity among states is due to Egg Corp's definition of "free range," which is assumed to comply with the legislation since both are based on the recommendations of the 2000 report.

\section{Alternative accreditations}

A number of accreditation and logo schemes have developed since 2000 that are more focused on animal welfare and agro-ecological concerns and can be implemented in addition to or as alternatives to the Egg Corp scheme. The Royal Society for the Prevention of Cruelty to Animals (RSPCA) developed its own "paw of approval" accreditation system aimed at improving animal welfare in intense, industrial-scale facilities. ${ }^{\text {xviii }}$ Some small-scale farmers who were concerned about both animal welfare and agro-ecological issues developed alternative practices and additional auditing, accreditation, and logo systems to support these practices. The most significant of these systems are the Free Range Farmers Association of Victoria ${ }^{x i x}$ and Humane Choice. ${ }^{x x}$ The major organic accreditation systems in Australia (Australian Certified Organic ${ }^{\mathrm{xxi}}$ and NASAA $^{\text {xxii }}$ ) also include standards for egg production that require cage-free systems and access to pasture and the outdoors.

As Table 1 shows, the focus varies among these schemes, as does their definition of 
what counts as free range. The Egg Corp and RSPCA schemes both are aimed at setting minimum animal welfare standards for large-scale facilities, with the RSPCA "paw of approval" setting the bar considerably higher than the Egg Corp scheme. The alternative schemes, by contrast, aim to build aspirational standards on top of minimum animal welfare standards. They generally focus on fostering smaller-scale production (via lower stocking densities both indoors and out, limits on the numbers of birds per shed, and extensive requirements for maintaining and nurturing the range area), set higher animal welfare standards (by banning de-beaking and forced moulting), and address systemic agro-ecological and public health issues (via ecological management practices and banning the preventive use of antibiotics and other chemicals).

All the schemes operate via independent auditing and accreditation systems that the producers themselves pay for. The "industrial" schemes (RSPCA and Egg Corp) operate more as businesses, while most "alternative" schemes (Humane Choice and FRFA) operate more as clubs or communities of practice that facilitate the sharing of knowledge and skills, campaign for greater recognition in the marketplace, and lobby around the meaning of "free range." Australian Certified Organic now operates at a scale and level of professionalism that it, too, is becoming its own industry (see also Guthman 2011) that certifies some very large-scale egg production businesses, but a number of smaller-scale organic associations still exist that operate more as communities of practice.

Finally, there are also many small- and medium-scale farmers selling "organic" or "free-range" eggs in markets and small retailers who have not sought any accreditation because they do not know about it, feel they cannot afford it in time or money, or would not meet all the conditions of certification.

\section{THE MARKETS FOR FREE-RANGE EGGS}

On its surface, the industry-led consumer choice regulatory policy approach that the Australian agriculture ministers have chosen has resulted in the clearer differentiation of caged, barn, and free-range eggs, the expansion of the market for free-range eggs, and, presumably, at least incremental increases in the overall welfare of layer hens. It also created a very large - and ambiguous - category of free-range egg.

In theory, a consumer might be able to research and evaluate the various accreditation system used (see Table 1) to determine which free-range eggs credibly match their ethical "taste," and purchase accordingly. The "consumer's eye" data collected for this article, however, reveals that the choice of retailer largely dictates the brands of eggs available; the accreditation system that defines what "free range" means; and the quality and quantity of supporting information, stories, and representation available to make an informed choice (see Table 2). The moral and cognitive burden on the consumer who wishes to choose free range, therefore, goes beyond simply looking at a carton of eggs in a retail display to understanding how the product reached the supermarket shelf in the first place, and what relationships and values are institutionalized in the food chain that brought it there (see Miele and Evans 2010).

The supermarket "duopoly"

Between them, the Coles and Woolworths supermarket chains make 80 percent of general grocery sales (Ferrier Hodgson 2011) and 50 percent of egg sales (ACCC 2008, 266) in Australia. A consumer entering the eggs aisle of a store in either of these chains will see about 50 percent of shelf space devoted to cage-free eggs, ${ }^{\text {xiii }}$ with the same 
fourteen varieties supplied by five companies. ${ }^{\text {xiv }}$ Both supermarkets also sell their own private label free-range and barn (as well as caged) eggs. In addition, both supermarket chains sell some local and premium free-range eggs in particular regions or stores. There is never more than one premium brand available in a particular store (in many stores no premium brand is available), and it retails for a much higher price (around AUD $\$ 9$ compared with a maximum of AUD $\$ 6.50$ for other free-range brands, if certified organic). In Canberra and Sydney, organic accredited eggs are available (for around AUD \$7.00), while in Melbourne one premium brand accredited by the Free Range Farmers Association is widely available.

The sheer number of different brands and styles of eggs available in Coles and Woolworths appears to give consumers a choice about the way the eggs they buy are produced. Yet the chain of production and distribution behind most of the twenty or so cage-free brands available appears to be largely the same (apart from the premium brands). To meet the supermarket chains' conditions of supply, concentrated producers and distributors must produce free-range eggs intensely and on an industrial scale. Besides the large quantities that they demand from their suppliers, both supermarket chains set many and onerous supply conditions, focusing on consistency and reliability of look and quality, the ability to supply nationally, and assurance of food safety, generally requiring suppliers' adherence to best practice industry standards demonstrated through third-party auditing and accreditation. In the case of eggs, this means that suppliers are required to have Egg Corp quality-assured accreditation, with those that are labeled organic required to have an additional organic certification. ${ }^{\mathrm{xxv}}$ Most eggs sold in supermarkets, however, do not display their Egg Corp accreditation on the cartons where consumers can see it, although they are required by the supermarket to have it - a good sign that it is the supermarket and its conditions of supply that really regulate the supply chain, not the consumer who instead trusts the supermarket to present appropriate choices (see also Richards et al. 2013; Richards, Lawrence, and Burch 2011).

Above all this, price is of supreme importance, especially for a staple item, such as eggs, that will bring customers into the store and encourage them to stay to buy other products. Discourse from both supermarket chains centers around "affordability" for customers and "economies of scale" (Coles 2010; Gettler 2009; Peddie 2012). ${ }^{\text {xxvi }}$ Since 2009 , both supermarket chains have sought to demonstrate their commitment to animal welfare by announcing that they are phasing out their own private label caged egg lines and dropping the price of free-range eggs (and exerting their market influence to demand lower costs from producers) (Miletic 2010; Watson 2009). ${ }^{\text {xvii }}$ At the same time, since Australian grain markets were deregulated, the global commodities markets have determined the major cost of egg production - the cost of the half-cup or so of grain ${ }^{\mathrm{xxviii}}$ that is fed to each hen per day. Grain forms up to 70 percent of Australian egg producers' costs, ${ }^{\mathrm{xxix}}$ and as most do not grow, mill, and mix (for appropriate protein and nutrient levels) their own feed, they are squeezed between the global grain commodities markets and the supermarket chains' price demands. ${ }^{\mathrm{xx}}$

It is therefore the combination of price pressure from Coles and Woolworths, the cost of the grain for the hen's feed as set by global commodities markets, and the ease and relatively low cost of refrigerated transport that make concentrated, intensive production and distribution attractive. The low standards for "free range" in the Egg Corp scheme facilitate the creation of this "industrial free range" (my term). They set the 
conditions for what "free range" - to be commercially viable - must mean for the chain that supplies eggs to the supermarket.

At present, Coles classifies 10,000 chickens per hectare as "free range" for the purposes of its private label free-range eggs, and a spokesman for Coles has warned that a stocking density of 1,500 hens per hectare would make free-range eggs unaffordable for many consumers (Peddie 2012). Similarly, Egg Corp has pointed out that the 1,500 hens per hectare figure "was created in 2001 at a time when the free-range egg market was in its infancy ( 8 percent market share in 2001) compared to the growth it is experiencing today (25 percent market share in 2011) and therefore does not represent the reality of the market today and into the future" (AECL 2012a). They argued that their proposed maximum stocking density of 20,000 hens per hectare is needed to avoid prices "soaring" to up to AUD\$12.80 per dozen (AECL 2012a). The scale and density of birds in intensive, industrial free-range systems, along with the size and number of holes to access the outdoors, make it likely that most birds will remain inside for much of their lives (ACCC 2012). One Australian research study showed that, on the average intensive freerange farm, only 9 percent of hens actually use the range area, due in part to their fear of the lack of shelter and overhead cover in most ranges (Poultry Hub 2010). But if all the hens went outside, with stocking densities of 20,000 hens per hectare (or even 10,000 hens per hectare), the range would be very quickly stripped bare (see ACCC 2012; Loughnan 2012; White 2009; Weis 2007). Moreover, since intensive, industrial-scale barn and free-range systems can feature higher hen mortality than can cage production, due to feather pecking, cannibalism and parasitic disease (SCARM Working Group 2000), there may also be increased use of beak-trimming; ironic, as this reduces the birds' ability to forage, and when such natural behaviors are inhibited, birds are even more likely to be inclined to peck feathers and be cannibalistic (ACCC 2012).

The consumer who pays a couple of dollars more for the free range available at the supermarket is essentially reinforcing the industrial food system. However, he or she will not necessarily realize this since the text and graphics on the labels mostly focus on selling a story about the authenticity of the farm, the happiness of the hens, and the lifestyle values that the eggs represent. These labels do more to obscure production conditions than they do to inform the consumer about the way the eggs were produced (see Parker, Kotey, and Brunswick, forthcoming; see also Richards, Lawrence, and Burch 2011). Most labels do not tell the consumer things such as what the stocking density is, what proportion of birds access the range for what length of time, or whether birds are debeaked. Nor do the supermarkets clearly display signage differentiating free-range from caged eggs and explaining what each means - except in Canberra where legislation requires this. ${ }^{\text {xxxi }}$ These practices all seem to assume that the consumer will simply trust the supermarket's judgment to "regulate" the product's safety, reliability, and labeling claims. It is possible - yet not easy - for a member of the public to find information online about the quality assurance procedures for Coles' and Woolworths' suppliers, but this information is not advertised to consumers. The Egg Corp scheme supports the supermarket approach rather than informing, satisfying or empowering consumers. This reflects global trends toward the concentration of grocery retailers (Richards et al. 2012) and the valorization of low consumer prices (the lowest ever in human history as a proportion of income; Carolan 2011, 2), convenience, and reliability, which have led to large-scale, concentrated, and efficient production and distribution that is carried through 
all processes that bring the supermarket free-range egg to market, and have affected the hens themselves and the ecological systems in which the facilities are located. Similar conditions appear to be present in the U.S. market where organic eggs dominate the cagefree market (see Cornucopia Institute 2010).

\section{"Independent" supermarkets and fresh produce stores}

The smaller supermarkets, usually referred to as the "independents," appear to follow the strategies of the duopoly supermarkets but often lack one or another of the factors of the major chains' success: management and quality assurance systems, economies of scale, and buying power. They stock free-range eggs that use similar branding styles to those in Coles and Woolworths but often look a bit less glossy and professional. The other major mainstream competitors to Coles and Woolworths, the independent fresh produce stores, greengrocers, and urban markets sell an even more diverse range of noncaged eggs than do Coles and Woolworths. Investigation showed that some of these brands were in fact supplied by some of the same companies that supply Coles and Woolworths, while others were supplied by less reputable suppliers offering little evidence that they had free-range accreditation even according to the Egg Corp definition. Occasionally eggs produced by a small-scale, local, alternative free-range or organic producer are available at these stores.

On the whole, the noncaged eggs for sale at all these retailers feature very little information about the production conditions; even the general stories told on the cartons sold at Coles and Woolworths lack such information. The cartons rarely feature any accreditation claims or logos on the cartons, in their display and marketing, or on their websites. It is possible that some of these retailers do in fact require Egg Corp accreditation or otherwise check the bona fides of the free-range eggs they stock. Individual managers of particular supermarkets or greengrocers might personally know all about where the eggs come from and what their claim of "free range" means. But if they do, generally neither the retailer nor the supplier informs consumers of this. There was often insufficient information on the cartons to help the consumer even identify the producer let alone where and how the eggs were produced and whether they were accredited by Egg Corp or anyone else.

It is just as likely that many of these free-range brands do not meet any particular definition of free range and are sold by retailers who may or may not check the production conditions. In this situation, the claims may be quite misleading and-given the price premium available for free range - it is highly likely that there are some situations where caged eggs are being sold as "free range,"xxxii or where the "free-range" eggs are produced in considerably worse conditions than even the conditions for the industrial free-range eggs sold at Coles and Woolworths. The eggs available at the largest competitor to the duopoly, the IGA chain of stores, varied considerably. Since each store operates as a franchise with its own management, some stores stock premium and local brands that may meet quite high standards of "organic" or "free range." The only information we could find for one highly available brand, however, was a Facebook page that appeared to extol the virtues of cage production in preference to free range. Another brand of (nonaccredited) "organic" eggs stated on the side of its carton that the eggs were "hen coop" eggs (meaning caged; the parent company's website confirmed this). ${ }^{\text {xxiii }}$

Where stores or small chains are independently owned, or choose to distinguish themselves via a different sourcing strategy to the majors, consumers who do ask about 
the conditions under which the eggs are produced and start asking for eggs that have relevant accreditations may be able to make a difference in the retailers' practices. This might in turn help to create alternative supply chains. Here, then, is a live battleground where consumers might make a difference in what "free range" means as the independents and greengrocers carve out some market against the ever-expanding supermarket duopoly.

The current modus operandi of the supermarkets (destroying competition in local shopping centers; squeezing suppliers with price, quality, and consistency demands; and refusing to deal with small-scale farmers) (see ACCC 2008; Master Grocers Australia 2012), may however ultimately destroy these alternative products and retail sites, whether by undercutting them on price or convenience or inducing them to seek concentrated, industrialized supply chains themselves. Clearly Egg Corp's revised quality assurance standard is positioning itself to provide the same production and distribution pathway for the "independents" to follow the lead of Coles and Woolworths in assuring the "free range" claim via large-scale, intensive production and distribution, and to compete on their turf using the same logic and values of supply.

Organic stores and farmers' markets

The retail share of farmers markets and other alternative fresh food markets is small but significant (7 percent in 2011 [not including organic stores]; DAFF 2011), and growing quickly. A consumer who walks into a specialist organic or whole foods store or a farmers market is much more likely to find brands with specific information about production conditions, including alternative "free-range" or "organic" accreditation logos, than one who walks into a Coles or Woolworths. The contemporary farmers' market model sprouted in Australia in the late-1990s, and patronage has steadily increased to support an estimated 150 farmers' markets nationally (Outer-Suburban/Interface Services and Development Committee 2010, 17). This represents a doubling of farmers' markets since 2004, with market managers reporting rising numbers of both stallholders and shoppers (Australian Farmers' Markets Association 2012). Meanwhile, eating organic food is becoming more popular (Lockie et al. 2004). Consumer demand for organic produce is outstripping supply, increasing at a rate of 20-30 percent yearly (Lockie et al. 2002). The retail organic market grew to $\$ 1.15$ billion in 2012 , with growth projected to continue at a rate of 10-15 percent per annum (Biological Farmers of Australia [BFA] 2012, 11).

Since many farmers markets are part of an association that has its own emerging accreditation system that requires all stalls to be staffed by the farmers themselves, ${ }^{\text {xxxiv }}$ the consumer can ask the farmer directly about production methods. In some cases, the farmers' market also requires all produce to come from within a certain radius of the market. ${ }^{\mathrm{xxv}}$ Organic and whole foods stores specialize in organic products and often have their own philosophy and checking and assurance mechanisms, with some requiring all products to be certified organic and others doing their own personal checking or production considerations. Thus, even more than Coles and Woolworths, the alternative retailers' (differently oriented) regulation of their suppliers is often an important part of these stores' business models. This is not always true, and as farmers' markets and organic and whole foods retail grow, there will likely be many entrants that seek a free ride on the reputation of those with more stringent standards, as well as those that seek to 
stretch the boundaries of "free range" closer to the Egg Corp model to extend their market.

The most "alternative" free-range eggs are available at farmers' markets direct from the farmer to the consumer. The packaging and, more importantly, the context sell a story of a shorter distance and greater connection among the hen and the farm and the consumer (Richards, Lawrence, and Burch 2011, 31). Many of the Melbourne farmers' market stalls displayed poster boards and other literature that showed pictures of the farm, with information about the living conditions of the hens. Those that had FRFA or Humane Choice accreditation also often displayed pictures and information about dominant battery caged egg production or even industrial-scale free range (e.g., pictures of beak-trimmed birds and stories about the pain this caused). Many of the farmers that did not have detailed information were willing to answer questions and seemed accustomed to consumers who wanted to know the answers.

\section{CONCLUSION}

The consumer choice approach to free-range egg regulation and labeling in Australia "responsibilizes" (Clarke 2005; Gray 2009; see also Roff 2007) consumers more than it empowers them. It appears to give consumers the power to "regulate" the food chain by choosing the production method that they want to valorize, but in reality it creates a distinction between those who are "ethically competent" (Miele and Evans 2010) consumers who are willing, able, and informed enough to invest time, money, and social and emotional intelligence into seeking out information and retail spaces where they can find alternatives - and those who allow the dominant retailers to construct their choices for them. Consumers may appear to be able to vote with their forks, but actively, ethically "competent," engaged, or "reflexive" consumers can exercise their responsibility only by patronizing a niche market of organic stores and farmers' markets (Roff 2007). The rest must be satisficed (Simon 1956) with supermarket-assured "industrial free range."

These different retail outlets are the end points of quite different supply chains that institutionalize different relationships, actions, and values; and the supply chain that ends with the two dominant supermarket chains dominates egg sales. The contest over Egg Corp' s proposed revised definition of "free range" is really over whether the different supply chains will continue to co-exist, whether the alternative chain will grow at the expense of or otherwise substantially disrupt the dominant chain, or whether the dominant chain will adjust and be able to encompass the alternative chain. At stake are different players' attempts to stabilize and commodify different ways of connecting the food chain among earth and sun, hen and farmer, distributor, marketer and retailer, and consumer, that will differentiate noncaged egg products and markets in different ways that can be legitimated by different values (see Boltanski and Thevenot 1991/2006; King and Pearce 2010; Weber, Heinze, and Desoucey 2008).

The two major supermarkets and the large egg producers (through their industry association) have been able to manipulate, coopt, and make ambiguous the definition of "free range" because consumers have little reliable access to alternative retail options, and there has been no regulatory intervention or market innovation that has substantially transformed the supermarket product or constructed a pervasive alternative to supermarket eggs. To put it another way, alternative egg producers have little access to supermarkets and supermarkets have much of the power to "regulate" what consumers 
see and can buy and therefore what "choices" are available to them. However, the organic store and farmers' market segments are growing, suggesting possibilities for expanding consumer choice through the availability of new products in new retail spaces, although these, too, will be subject to pressure to upscale, industrializes, and, therefore, make more ambiguous their free-range and organic standards (see Arcuri 2012; Guthman 2004). The controversy over Egg Corp's revised definition of "free range" has also created so much media attention and consumer talk that it may well shift the meaning of free range in the supermarkets and encourage more consumers to find alternative outlets.

At the same time, the debate over the meaning of "free range" distracts from discussions of an alternative policy path: that Australian governments could be setting and enforcing higher standards for factory farming that would socialize the animal welfare, agro-ecological, and public health costs of egg production and remove the choice of "unethical" eggs all together (see McEwen 2011, 1-5; see also Kirby 2012). In particular, the debate distracts attention from the ongoing campaign to ban caged egg production, or at least require "enriched" cages, as is the case in the EU and some U.S. states. ${ }^{\text {xxxvi }}$ Other regulatory options might include regulation or tax incentives to encourage or ensure waste is recycled and re-used in a sustainable way and that hens are kept in smaller groups on more land. These regulatory options could move the whole market by establishing a floor for allowable practices and thereby allowing more room at the top for innovation and differentiation. Similarly, a serious policy approach to food miles or carbon outputs might significantly change the power of the large producers and retailers in the market and valorize local, pervasive egg farming (rather than pervasive egg transport). Conversely, regulation could be used to subsidize, incentivize, or set aside land for alternative farmers (e.g., tax incentives for family farms that use organic methods for egg production in a mixed farm) and alternative retail spaces that would help to create new product categories and markets.

Sometimes policy-oriented literature on business regulation asks which regulatory technique is most effective at constraining which organizations in which circumstances. This tends to assume that the regulation of powerful businesses can be divided into individual regulatory interventions and their effects on individual organizations. This article suggests that understanding the impact of regulation is not merely about evaluating whether and when each business listens and complies (cf Parker and Nielsen 2011). Rather, the most far-reaching impacts of regulation are seen in how it constitutes and changes whole markets by privileging or constraining, or empowering or ignoring the various actors, interests, and goals in the networks of production, distribution, exchange, and consumption that create each market (see Sewell 1992; Swidler 1986). Regulatory technique is not merely an instrumental choice about how to regulate markets most effectively, or even a political choice about how to achieve some kind of regulation in the face of necessary political compromises. Rather, it is a substantive value choice that privileges certain actors, interests, and values in the chain of production and puts others out of sight. However, it is not specific policy ideas and alternative regulatory options that are important for this analysis, it is the overall picture of how regulatory choices have helped to constitute where the market and cultural power lies in the growth of "freerange" eggs, and how things could have been arranged differently. In the case of eggs, regulatory technique has enormous implications for the lives of hens, for the sustainability of small-scale and local egg farms, and, potentially, for public health. 


\section{REFERENCES}

American Egg Board. 2012. Egg industry facts sheet. Available from http://www.aeb.org/egg-industry/industry-facts/egg-industry-facts-sheet (accessed 5 December 2012).

Arcuri, Alessandra. 2012. The transformation of organic regulation: The ambiguous distributional effects of "publicization." Paper presented at BACT Seminar, Erasmus School of Law, Erasmus University, 28 Septemberg 2012. Rotterdam.

Australian Bureau of Statistics (ABS). 2011. Value of agricultural commodities produced 2010 - 11.Canberra: Commonwealth of Australia.

Australian Competition and Consumer Commission (ACCC). 2008. Report of the ACCC inquiry into the competitiveness of retail prices for standard groceries. Canberra: Commonwealth of Australia.

Australian Competition and Consumer Commission (ACCC). 2012. Initial assessment of Certification Trade Mark application CTM1390450 filed by the Australian Egg Corporation Limited. Canberra: ACCC.

Australian Egg Corporation Limited (AECL). 2005. Unifying for results: Annual report. North Sydney, AU: AECL.

Australian Egg Corporation Limited (AECL). 2006. Project report. North Sydney, AU: AECL.

Australian Egg Corporation Limited (AECL). 2007. Protecting our future: 2007 annual report. North Sydney, AU: AECL.

Australian Egg Corporation Limited (AECL). 2008. Annual report: Five years on. North Sydney, AU: AECL.

Australian Egg Corporation Limited (AECL). 2009. Annual report: From the farm to the table. North Sydney, AU: AECL.

Australian Egg Corporation Limited (AECL). 2010a. Annual report: From the farm to the table. North Sydney, AU: AECL.

Australian Egg Corporation Limited (AECL). 2010b. Egg labelling guide. North Sydney, AU: AECL.

Australian Egg Corporation Limited (AECL). 2011. Annual report. North Sydney, AU: AECL.

Australian Egg Corporation Limited (AECL). 5 February 2012 (2012a). Egg consumption cracks new heights, media release. Available from http://www.aecl.org/system/attachments/497/original/Egg\%20Consumption\%20Crack s\%20New\%20Heights.pdf?1328825645 (accessed 23 November 2012).

Australian Egg Corporation Limited (AECL). 2012b. Fact sheet: Free range stocking densities. Available from http://www.aecl.org/system/attachments/511/original/Free\%20range\%20stocking\%20d ensity\%20fact\%20sheet.pdf?1334129238 (accessed 23 November 2012).

Australian Farmers' Markets Association. 5 April 2012. Farmers' markets a growing food source, media release. Available from http://www.farmersmarkets.org.au/news/afmamedia-release/farmers-markets-strong-growth-official (accessed 9 January 2013).

Biological Farmers of Australia (BFA). 2012. Australian organic market report. Nundah, AU: BFA.

Boltanski, Luc, and Laurent Thevenot. 1991/2006. On justification: Economies of worth. Princeton, NJ: Princeton University Press. 
Wiley, Kip, Nick Vucinich, John Miller, and Max Vanzi. 2004. Confined animal facilities in California. Prepared for the California State Senate. Sacramento, CA: Government of California.

Cao, Deborah. 2010. Animal law in Australia and New Zealand. Sydney: Thomson Reuters.

Carolan, Michael. 2011. The real cost of cheap food. London: Earthscan.

Clarke, John. 2005. New labour's citizens: Activated, empowered, responsibilized, abandoned? Critical Social Policy 25 (4): 447-63.

Coles. 18 November 2010. Coles Cuts Free Range Egg Prices to Help Customers Switch from Caged Eggs, media release. Available from

https://www.coles.com.au/Portals/0/content/pdf/News/Free\%20Range\%20Eggs\%20M edia\%20Release\%20National.pdf (accessed 28 November 2012).

Cornucopia Institute. 2010. Scrambled eggs: Separating factory farm egg production from authentic organic agriculture. Available from http://www.cornucopia.org/2010/09/organic-egg-report-and-scorecard/ (accessed 24 November 2012).

Dale, Arnja. 2009. Animal welfare codes and regulations: The devil in disguise? In Animal law in Australia: A new dialogue,eds. Peter J. Sankoff and Steven William White, 174-211. Sydney: The Federation Press.

Department of Agriculture, Fisheries, Forestry and Farming (DAFF). 2011. Australian food statistics 2010-2011. Canberra: DAFF.

Ewick, Patricia, and Susan Silbey. 1998. The common place of law: Stories from everyday life. Chicago, IL: The University of Chicago Press.

Ferrier Hodgson. 11 May 2011. Supermarkets shootout: Will the independents survive? Ferrier Focus.

Fung, Archon, Mary Graham, and David Weil. 2007. Full disclosure: The promise and peril of transparency. Cambridge: Cambridge University Press.

Gettler, Leon. 19 August 2009. Issue of Free Range Eggs Cracked at Woolworths. Green Lifestyle Magazine. Available from http://www.gmagazine.com/news/1523/issue-freerange-eggs-cracked-woolworths (accessed 21 November 2012).

Gray, Garry C. 2009. The responsibilization strategy of health and safety: Neo-liberalism and the reconfiguration of individual responsibility for risk. British Journal of Criminology 49:326-42.

Guthman, Julie. 2004. Agrarian dreams: The paradox of organic farming in California. Berkeley, CA: University of California Press.

Guthman, Julie. 2011. Weighing in: Obesity, food justice and the limits of capitalism. Berkeley, CA: University of California Press.

Independent Panel for the Review of Food Labelling Law and Policy (IPRFLLP). 2011. Labelling logic: Review of food labelling law and policy (Commissioned by the Australia and New Zealand Food Regulation Ministerial Council). Canberra: Commonwealth of Australia.

King, Brayden G., and Nicholas A. Pearce. 2010. The contentiousness of markets: Politics, social movements, and institutional change in markets. Annual Review of Sociology 36:249-67.

Kirby, David. 2012. Animal Factory. St Martin's Press.

Levi-Faur, David. Forthcoming. Regulating capitalism: A constitutive approach. 
Lockie, Stewart, Kristen Lyons, Geoffrey Lawrence, and Kerry Mummery. 2002. Eating "green": Motivations behind organic food consumption in Australia. Sociologia Ruralis 42 (1): 23-40.

Lockie, Stewart, Kristen Lyons, Geoffrey Lawrence, and Janet Grice. 2004. Choosing organics: A path analysis of factors underlying the selection of organic food among Australian consumers. Appetite 43:135-46.

Loughnan, Diane. 2012. Food shock. Wollombi: Exisle Publishing.

McEwen, Graeme. 2011. Animal law: Principles and Frontiers. Australia: BAWP, PDF ebook.

McKenna, Maryn. 2010. Superbug: The fatal menace of MRSA. New York, NY: New York Free Press.

Master Grocers Australia. 2012. Let's have fair competition! The risk of losing retail diversity, choice and true competition in the Australian supermarket industry. Malvern: Master Grocers Australia.

Miele, Mara, and Adrian Evans. 2010. When foods become animals: Ruminations on ethics and responsibility in care-full practices of consumption. Ethics, Place and Environment 13:171-90.

Miletic, Daniela. 18 November 2010. Coles to cut price of free range eggs. Sydney Morning Herald. Available from http://www.smh.com.au (accessed 22 November 2012).

Morgan, Kevin, Terry Marsden, and Jonathan Murdoch. 2009. Worlds of food: Place power and provenance in the food Chain. Oxford: Oxford University Press.

Nierenberg, Danielle. 2005. Happier meals: Rethinking the global meat industry. Washington, DC: Worldwatch Institute.

Outer-Suburban/Interface Services and Development Committee. 2010. Inquiry into farmers' markets. East Melbourne: Parliament of Victoria.

Outlaw, Kiera. 2012. Eggs farming in Australia: Industry risk rating report. Melbourne: IBISWorld.

Parker, Christine, and Vibeke Lehmann Nielsen. 2009. The challenge of empirical research on business compliance in regulatory capitalism. Annual Review of Law and Social Sciences 5:45-70.

Parker, Christine, and Vibeke Lehmann Nielsen. 2011. Explaining compliance: Business responses to regulation. Cheltenham, UK: Edward Elgar.

Parker, Christine, Jane Kotey, and Carly Brunswick. Forthcoming. The happy hen on your supermarket shelf: What choice does industrial strength free range represent for consumers? Journal of Bioethical Enquiry.

Peddie, Claire. 7 June 2012. Free-range eggs panned in coles collision course. The Advertiser. Available from http://www.adelaidenow.com.au/free-range-eggs-pannedin-coles-collision-course/story-e6frea6u-1226388123417 (accessed 23 November 2012).

Pickett, Heather. 2003. Industrial animal agriculture. Hampshire: Compassion in World Farming.

Pollan, Michael. 7 May 2006. Vote with your fork. The New York Times. Available from http://pollan.blogs.nytimes.com/2006/05/07/voting-with-your-fork/ (accessed 7 January 2012).

Poultry Hub. 31 August 2010. Enriching the range to reduce feather pecking. eChook 
News. Available from http://www.poultryhub.org/2010/08/enriching-the-range-toreduce-feather-pecking/ (accessed 29 November 2012).

Primary Industries Standing Committee. 2002. Model code of practice for the welfare of animals: Domestic poultry (SCARM Report no. 83). Collingwood, AU: CSIRO Publishing.

Richards, Carol, Geoffrey Lawrence, and David Burch. 2011. Supermarkets and agroindustrial foods. Food, Culture and Society 14:29-47.

Richards, Carol, Hilde Bjorkhaug, Geoffrey Lawrence, and Emmy Hickman. 2013. Retailer-driven agricultural restructuring: Australia, the UK and Norway in comparison. Agriculture and Human Values doi: 10.1007/s10460-012-9408-4.

Roff, Robin Jane. 2007. Shopping for change? Neoliberalizing activism and the limits to eating non-GMO. Agriculture and Human Values 24:511 - 22.

Royal Society for the Prevention of Cruelty to Animals (RSPCA). 2012a. Hens Deserve Better: Frequently Asked Questions. Available from http://www.hensdeservebetter.org.au/the-details/faq.html (accessed 16 November 2012).

Royal Society for the Prevention of Cruelty to Animals (RSPCA). 2012b. Hens deserve better: Behaviour. Available from http://www.hensdeservebetter.org.au/thedetails/behaviour.html (accessed 16 November 2012).

SCARM Working Group. 2000. Synopsis report on the review of layer hen housing and labelling of eggs in Australia. Canberra: Australian Department of Agriculture, Fisheries and Forestry. Available from http://www.daff.gov.au/animal-planthealth/welfare/reports/layer-hen (accessed 1 November 2012).

Senate Economics Legislation Committee. 2011. Constitutional Corporations (Farm Gate to Plate) Bill 2011 Senate Economics Legislation Committee 15 November 2011. Canberra: Commonwealth of Australia.

Sewell, William H. 1992. A theory of structure: Duality, agency and transformation. American Journal of Sociology 98:1-29.

Sharman, Katrina. 2009. Farm animals and welfare law: An unhappy union. In Animal law in Australia: A new dialogue, eds. Peter J. Sankoff and Steven William White, 3556. Sydney: The Federation Press.

Simon, Herbert A. 1956. Rational choice and the structure of the environment. Psychological Review 63 (2): 129-38.

Singer, Peter, and Jim Mason. 2006. The ethics of what we eat. Melbourne: The Text Publishing Company.

Smith, Dorothy. 2005. Institutional ethnography: A sociology for people. Lanham, MD: Rowman and Littlefield Publishers.

Swidler, Ann. 1986. Culture in action: Symbols and strategies. American Sociological Review 51:273-86.

Watson, Rhett. 14 August 2009. Shopping Giant Woolworths Goes Free Range with Eggs. The Telegraph. Available at http://www.dailytelegraph.com.au (accessed 22 November 2012).

Weber, Klaus, Kathryn L. Heinze, and Michaela Desoucey. 2008. Forage for thought: Mobilizing codes in the movement for grass-fed meat and dairy. Administrative Science Quarterly 53:529-67.

Weis, Tony. 2007. The global food economy: The battle for the future of farming. London: 
Zed Books.

White, Leslie. 19 August 2009. Egg growers crack it. Weekly Times. Available from http://www.weeklytimesnow.com.au/article/2009/08/19/104761_on-farm.html (accessed 23 November 2012).

WSPA. n.d. Beyond battery cages: A humane, sustainable model of egg production in the Netherlands. London: World Society for the Protection of Animals. 
TABLE 1 SUMMARY OF MAJOR ACCREDITATION STANDARDS FOR FREERANGE EGG PRODUCTION IN AUSTRALIA

\begin{tabular}{|c|c|c|c|c|c|}
\hline & 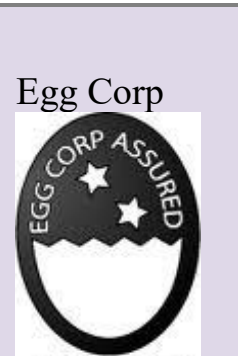 & RSPCA & $\begin{array}{l}\text { Free Range } \\
\text { Farmers } \\
\text { Association } \\
\text { Victoria }\end{array}$ & 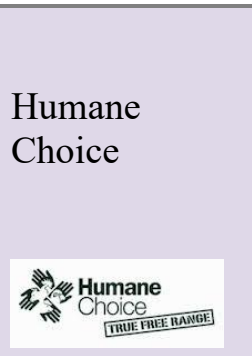 & $\begin{array}{l}\text { Australian } \\
\text { Certified } \\
\text { Organic } \\
\text { (a) AUSTRALIAN } \\
\text { ORGAFIIC }\end{array}$ \\
\hline Density inside & 15 birds $/ \mathrm{m}^{2}$ & $7-9 \operatorname{birds} / \mathrm{m}^{2}$ & 7 birds $/ \mathrm{m}^{2}$ & 5 birds $/ \mathrm{m}^{2}$ & 7 birds $/ \mathrm{m}^{2}$ \\
\hline $\begin{array}{l}\text { Max birds per } \\
\text { shed }\end{array}$ & No maximum & $\begin{array}{l}5000 \text { (recc- } \\
\text { ommended } \\
\text { only.) }\end{array}$ & 1000 & 2500 & 1500 \\
\hline Density outside & $\begin{array}{l}\text { No maximum } \\
\text { (rotation) } \\
1,500 \\
\text { birds/hectare } \\
\text { (ha) } \\
\text { (no rotation) }\end{array}$ & $\begin{array}{l}2,500 \\
\text { birds/ha } \\
\text { (rotation) }\end{array}$ & $750 \mathrm{birds} / \mathrm{ha}$ & $1,500 \mathrm{birds} / \mathrm{ha}$ & $\begin{array}{l}\text { 1,000birds/ } \\
\text { ha }\end{array}$ \\
\hline $\begin{array}{l}\text { Groundcover } \\
\text { requirements? }\end{array}$ & No & Yes & Yes & $\begin{array}{l}\text { Yes } \\
\text { (extensive) }\end{array}$ & $\begin{array}{l}\text { Yes } \\
\text { (very } \\
\text { extensive) }\end{array}$ \\
\hline Beak trimming? & Yes & $\mathrm{No}^{\mathrm{a}}$ & No & No & $\mathrm{No}^{\mathrm{a}}$ \\
\hline $\begin{array}{l}\text { Induced } \\
\text { moulting? }\end{array}$ & Yes & No & No & No & No \\
\hline $\begin{array}{l}\text { Allows cage } \\
\text { production on } \\
\text { same farm? }\end{array}$ & Yes & Yes & No & No & No \\
\hline Antibiotics? & Yes & Yes $^{b}$ & No & Yes $^{\mathrm{b}}$ & Yes $^{\mathrm{b}}$ \\
\hline $\begin{array}{l}\text { Yolk colorant in } \\
\text { feed? }\end{array}$ & Yes & Yes & No & Not specified & $\begin{array}{l}\text { Synthetic } \\
\text { coloring } \\
\text { prohibited }\end{array}$ \\
\hline $\begin{array}{l}\text { Mostly sold } \\
\text { where? }\end{array}$ & $\begin{array}{l}\text { Dominant } \\
\text { supermarket } \\
\text { chains }\end{array}$ & $\begin{array}{l}\text { Dominant } \\
\text { supermarket } \\
\text { chains }\end{array}$ & $\begin{array}{l}\text { Farmers' } \\
\text { markets/ } \\
\text { Organic } \\
\text { stores } \\
\text { (Victoria } \\
\text { only) }\end{array}$ & $\begin{array}{l}\text { Farmers' } \\
\text { markets/ } \\
\text { Organic stores }\end{array}$ & $\begin{array}{l}\text { Organic } \\
\text { stores }^{c}\end{array}$ \\
\hline
\end{tabular}




\begin{tabular}{|l|l|l|l|l|l|}
\hline $\begin{array}{l}\text { Scale of farms } \\
\text { mostly } \\
\text { accredited? }\end{array}$ & $\begin{array}{l}\text { Intensive, } \\
\text { industrial, } \\
\text { and medium } \\
\text { scale }\end{array}$ & $\begin{array}{l}\text { Intensive, } \\
\text { industrial }\end{array}$ & $\begin{array}{l}\text { Small scale, } \\
\text { alternative } \\
\text { farmers and } \\
\text { medium } \\
\text { scale }\end{array}$ & $\begin{array}{l}\text { Small scale, } \\
\text { alternative } \\
\text { farmers and } \\
\text { medium scale }\end{array}$ & All \\
\hline
\end{tabular}

a. But exceptions may be specifically allowed by the accrediting organization.

b. But not systematically, only for therapeutic purposes and under vet supervision.

c. Also available to limited extent in dominant supermarket chains and farmers markets in ACT and NSW 
TABLE 2

RETAIL MARKETS FOR FREE-RANGE EGGS

\begin{tabular}{|c|c|c|c|}
\hline & $\begin{array}{l}\text { The } \\
\text { Supermarket } \\
\text { Duopoly }\end{array}$ & $\begin{array}{l}\text { Independent } \\
\text { Supermarkets and } \\
\text { Fresh Produce } \\
\text { Stores }\end{array}$ & $\begin{array}{l}\text { Organic Stores } \\
\text { and Farmers' } \\
\text { Markets }\end{array}$ \\
\hline $\begin{array}{l}\text { Level of concentration } \\
\text { of producers, } \\
\text { distributors, and } \\
\text { retailers? }\end{array}$ & High & Both & Low \\
\hline $\begin{array}{l}\text { Retailed locally or } \\
\text { transported for } \\
\text { distant retail? }\end{array}$ & Distant & Both & Local \\
\hline $\begin{array}{l}\text { Consistent, } \\
\text { formalized regulation } \\
\text { and accreditation of } \\
\text { meaning of "free } \\
\text { range"? }\end{array}$ & Yes & No & Varies \\
\hline $\begin{array}{l}\text { Who regulates } \\
\text { meaning of "free } \\
\text { range"? }\end{array}$ & $\begin{array}{l}\text { Supermarkets } \\
\text { with support of } \\
\text { Egg Corp }\end{array}$ & None & $\begin{array}{l}\text { Small producer } \\
\text { associations }\end{array}$ \\
\hline $\begin{array}{l}\text { Type of information } \\
\text { about production } \\
\text { available at point of } \\
\text { retail? }\end{array}$ & $\begin{array}{l}\text { Marketing } \\
\text { statements; little } \\
\text { detailed } \\
\text { information }\end{array}$ & Virtually none & $\begin{array}{l}\text { Informative text } \\
\text { on label or } \\
\text { website; specific } \\
\text { information } \\
\text { often available } \\
\text { from farmer or } \\
\text { retailer }\end{array}$ \\
\hline $\begin{array}{l}\text { Style of } \\
\text { representation of } \\
\text { relationship between } \\
\text { hen and consumer at } \\
\text { point of retail }\end{array}$ & $\begin{array}{l}\text { Romanticized } \\
\text { photos and } \\
\text { stylized graphics }\end{array}$ & $\begin{array}{l}\text { Romanticized } \\
\text { photos and } \\
\text { graphics; plain } \\
\text { packaging }\end{array}$ & $\begin{array}{l}\text { Nonprofessional, } \\
\text { homemade look; } \\
\text { accurate looking } \\
\text { photos }\end{array}$ \\
\hline Values represented & $\begin{array}{l}\text { Consumer } \\
\text { convenience, low } \\
\text { cost, safety } \\
\text { assurance, choice } \\
\text { of animal welfare } \\
\text { and organic }\end{array}$ & $\begin{array}{l}\text { Consumer } \\
\text { convenience, low } \\
\text { cost }\end{array}$ & $\begin{array}{l}\text { Sense of } \\
\text { connection with } \\
\text { farm and hen, } \\
\text { local, fresh, } \\
\text { tasty, animal } \\
\text { welfare, agro- }\end{array}$ \\
\hline
\end{tabular}




\begin{tabular}{|l|l|l|l|}
\hline & options & & ecological \\
& & & \\
\hline
\end{tabular}

\section{Notes}

i See discussion in note 16 and accompanying text.

ii “Industry structure and organisations: Chicken egg (layer) industry," Poultry Hub, accessed 5 January

2013, http://www.poultryhub.org/production/industry-structure-and-organisations/egg-industry/.

iii By contrast, noncaged eggs account for only 5.7 percent of production in the United States (with 2.9

percent of these being organic) (American Egg Board 2012).

iv This is based on our own data collection in Canberra, Sydney, and Melbourne in 2012, described below.

v The RSPCA and Animals Australia both also advocate for animal lovers to "vote with your wallet." See http://www.rspca.org.au/what-we-do/working-with-farming-industry/approved-farming-scheme/;

http://www.freebetty.com/take_action_for_chickens.php.

vi See note 14. The term "battery" cage is used to denote small, barren, wire mesh cages used for layer hens. "Enriched" or "colony" cages are larger cages that include nests, perches, litter for pecking and scratching, and unrestricted access to a food trough.

vii We include "organic" as well as "free-range" eggs because the major "organic" certifications in Australia (Australian Certified Organic and NASAA) and internationally (e.g., USDA) require eggs to be produced in systems where cages are not used and hens have access to the outdoors.

viii See the campaigns by the RSPCA and Animals Australia referred to in note 5 .

ix This is set out in the voluntary Model Code of Practice for the Welfare of Animals: Domestic Poultry, and the relevant provisions have been legislated by most states and territories in Australia (Cao 2010, 212).

$\mathrm{x}$ Interview with egg farmer.

xi Interview with egg farmer. See also http://www.humanechoice.com.au/.

xii European Union Directive 1999/74/EC Starting January 1, 2003, new "non-enriched cage systems" were not allowed to be built or placed in use. As of January 2012, they were completely prohibited. Producers may use "enriched cages" (see note 6 for a definition) or a noncage system (with the same 
amenities as enriched cages and a stocking density that does not exceed nine laying hens per square meter of useable area indoors). There is no requirement for outdoor access. Switzerland had already banned battery cages in 1992. Germany, Austria, the Netherlands, and Sweden banned battery cages ahead of 2012, with other European-Union countries banning battery cages as of 2012 as required.

xiii Note that according to quarantine regulations, fresh eggs cannot be imported into Australia, but liquid or dried eggs for use in processed foods and catering by large hotel chains, hospitals, and airlines can be imported with permission.

xiv The Primary Industries Ministerial Council, a collaborative working group between State and Federal governments and other relevant agencies, affirmed this decision and the result was the revised 4th edition of the voluntary Model Code of Practice for the Welfare of Animals, Domestic Poultry (Primary Industries Standing Committee 2002). The definitions in the text are quoted from that edition of the Model Code of Practice. The synopsis report did recognize on pages 23-24 that some cage farms had completely outmoded shed equipment that needed to be replaced for economic and welfare reasons, and the space requirement for battery cages was slightly increased from the previous levels as a result.

xv See sections 9.6, 14.1, and 14.2 of the Egg Corporation Assured Auditor's Evidence Guide, v. 2.4 (2008) available at http://www.aecl.org/system/attachments/212/original/Auditors_Evidence_Guide_V2_4_160908.pdf. xvi Controversy centers on the interpretation of the clause in the Model Code of Practice that provides that there should be a maximum stocking density of 1,500 hens per hectare outdoors for a free-range system. There is a provision that follows this that says: "When meat chickens use only some of the 10 week cycle on pasture (e.g. 4 weeks) a proportionately higher stocking density than for layers may be used. NB Any higher bird density is acceptable only where regular rotation of birds onto fresh range areas occurs and close management is undertaken which provides some continuing fodder cover.” Egg Corp argues that the "NB" applies to layer hens as well, who are mentioned immediately preceding this provision. xvii Eggs (Labelling and Sale) Act 2001 (ACT). This legislation requires that both the packaging and display of eggs for retail sale must indicate the system (cage, barn, or free range) used to produce the eggs. The production systems are defined in accordance with the definitions in the Model Code of Practice. 
Caged eggs must be kept separate from the other eggs on the display and marked in red on the edge of the shelves.

xviii See http://www.rspca.org.au/what-we-do/working-with-farming-industry/approved-farming-scheme/ (accessed 10 January 2013).

xix See http://www.freerangefarmers.com.au/ (accessed 10 January 2013).

xx See http://www.humanechoice.com.au/ (accessed 10 January 2013).

xxi See http://www.australianorganic.com.au/ (accessed 10 January 2013).

xxii See http://www.nasaa.com.au/ (accessed 10 January 2013).

xxiii Shelves were photographed and the proportion devoted to cage-free eggs calculated and averaged.

xxiv Three companies produce and distribute nearly 50 percent of the retail eggs sold in Australia (Outlaw

2012). They are largely vertically integrated with each company responsible for its own production,

distribution, and branding for supermarket sale. They own their own egg production facilities and also have

supply agreements with smaller producers. Two emerging producers and distributors also supply noncaged eggs to Coles and Woolworths (and their smaller competitor supermarkets) around Australia.

xxv Woolworths' standards are available at www.wowlink.com.au and Coles' standards are available from https://www.supplierportal.coles.com.au/csp/wps/portal (accessed 29 November 2012).

xxvi Egg Corp has accused the supermarkets of slashing prices by reducing the number of egg suppliers and consolidating which brands they stock (White 2009). A Senate enquiry revealed that in the wake of the "Milk price wars," a major egg producer was approached by one of the big supermarkets that they had been supplying, under the implication that eggs were the next commodity to be subjected to such a price squeeze, with the supermarket stating the price they were willing to pay (Senate Economics Legislation Committee 2011).

xxvii See the animal welfare sections of the Coles and Woolworths websites: http://www.coles.com.au; http://www.woolworths.com.au (accessed 22 November 2012).

xxviii The feed usually contains wheat, sorghum, and barley, and can also contain rye, triticale, and oats. It must also include protein from vegetable sources, such as soybean, canola, cottonseed, and sunflower; meals and legumes, such as peas and lupins; or animal proteins, such as meat meal, meat, bone meal, fish 
meal, poultry by-product meal, blood meal, and feather meal. See

http://www.poultryhub.org/nutrition/feed-ingredients/ (accessed 27 November 2012).

xxix See http://www.poultryhub.org/nutrition/feed-ingredients/ (accessed 27 November 2012).

xxx According to one organic accreditation agency, the main reason that the cost of organic eggs is so much

higher is the high cost of organic grain (which is available from only one commercial supplier in Australia, in South East Queensland, thus involving considerable transport costs and food miles for those much further away than Sydney). Because organic grain growers can already obtain a premium for grain grown for direct human consumption, there is little incentive to grow organic grain at a reasonable price for animal food.

xxxi See note 17.

xxxii There have been a number of cases of misleading and deceptive labeling: ACCC $v$ Bruhn[2012] FCA 959 (5 September 2012). See also ACCC v CI \& Co Pty Ltd, Antonio Pisano and Anna Angelo Pisano

[2010] FCA 1511. There has also been at least one successfully prosecuted case where a producer put an organic accreditation logo on a carton of eggs without actually being certified: ACCC v G.O. Drew Pty Ltd [2007] FCA 1246.

xxxiii Caged eggs cannot be certified as "organic," but the feed for the caged hens may have been certified organic.

xxxiv This is a part of the charter of the Victorian Farmers' Market Association; see http://www.farmersmarkets.org.au/news/afma-media-release/victorian-farmers-market-association-charter. It is also a rule of many specific markets; see for example, EPIC market in Canberra, available at http://www.capitalregionfarmersmarket.com.au/information.html.

xxxv See, for example, the website of the Australian Farmers' Market Association; http://www.farmersmarkets.org.au/about/charter; see also http://www.capitalregionfarmersmarket.com.au/information.html. xxxvi For the EU, see note 12 and accompanying text. In the United States, California passed legislation in 2008 requiring battery cage production to be phased out by 2015 , and in 2010 it legislated to prohibit the sale of battery-cage eggs in California. Michigan and Ohio, both large egg-producing states, have passed similar legislation. Massachusetts, Washington, Arizona, and Oregon are considering such legislation. In 
2011 the Humane Society of the United States and United Egg Producers (the egg industry association) jointly drafted a federal bill that would ban battery cages and allow only enriched cages or noncage systems: HR 3798/S 3239. See http://www.eggbill.com (accessed 30 October 2012). 